\title{
Hubungan Pengetahuan, Sikap, dan Dukungan Keluarga Dengan Tindakan Cuci Tangan Untuk Pencegahan Covid-19 Pada Mahasiswa Poltekkes Kemenkes Jakarta III
}

\author{
Erna Sariana, Dwi Agustina \\ Program Studi Sarjana Terapan Fisioterapi Jurusan Fisioterapi Poltekkes Kemenkes Jakarta III \\ Email : ernasariana.es@gmail.com
}

\begin{abstract}
Abstrak
Pendahuluan: Corona Virus Disease (COVID-19) sudah ditetapkan oleh WHO sebagai pandemik. Meluasnya penyebaran COVID-19 di Indonesia menimbulkan perlunya dilakukan upaya pencegahan ditingkatkan, salah satunya melalui tindakan cuci tangan. Dari beberapa penelitian ilmiah menunjukkan bahwa tindakan cuci tangan menggunakan pembersih, dinilai sangat penting kaitannya dengan upaya pencegahan penyakit covid-19. Tujuan dari penelitian adalah menganalisis hubungan tingkat pengetahuan, sikap, dan dukungn keluarga dengan tindakan mencuci tangan pada usaha untuk mencegah penyakit Covid-19 pada mahasiswa Prodi Sarjana Terapan Fisioterapi Poltekkes Kemenkes Jakarta III. Metodologi: Jenis penelitiannya deskriptif dengan desain cross sectional (potonglintang). Sampel adalah sebagian mahasiswa Sarjana Terapan Fisioterapi yaitu 120 orang, dipilih melalui metode proporsional random sampling. Penelitian dilaksanakan bulan Juli September 2020. Data dikumpulkan memakai kuesioner melalui G-Form. Analisa data terdiri dari univariat, bivariat (uji Kai Kuadrat), dan multivariat (uji Regresi Logistik). Hasil penelitian: tindakan cuci tangan responden Sebagian besar termasuk kategori baik $(65,0 \%)$, responden memiliki pengetahuan tinggi $(59,2 \%)$, sikap positif $(57,5 \%)$, dan dukungan keluarga baik $(56,7 \%)$. Hasil analisis bivariat, seluruh variabel mempunyai hubungan yang signifikan dengan tindakan cuci tangan, yaitu pengetahuan $(p=0,013$ dan $O R=2,827$, sikap $(p=0,029$ dan $O R=2,519)$, dan dukungan keluarga ( $p$ $=0,0001$ dan $\mathrm{OR}=7,649)$. Hasil analisis multivariat, faktor dominan paling tinggi yang mempengaruhi tindakan cuci tangan adalah pengetahuan ( $O R=2,969)$. Saran: agar pihak kampus dapat memberikan pendidikan kesehatan, pemasangan pesan kesehatan di lingkungan kampus tentang pentingnya pencegahan Covid-19, menyediakan sarana cuci tangan yang mendukung.
\end{abstract}

Kata Kunci: Cuci Tangan, Pencegahan, Covid 19

\section{Abstract}

Introduction: WHO has established COVID-19 as a pandemic. The widespread spread of Corona Virus Disease (COVID-19) in Indonesia has led to various prevention efforts, one of which is through hand washing. From several scientific studies showing that the act of washing hands using a cleanser, is considered very important relation to efforts to prevent diseases that can be transmitted through hand media, such as covid-19 disease. The purpose of this study was to determine the relationship of the level of knowledge, attitudes, and family support with handwashing in the prevention of Covid-19 disease in students of the D-IV Physiotherapy Study Program at the Ministry of Health Jakarta III. Metodology: This type of research is descriptive with cross sectional design. Samples are 120 D-IV Physiotherapy students, who will be selected by proportional random http://ejournal.urindo.ac.id/index.php/jukmas 
sampling method. The research will be conducted in July - September 2020. Data were collected using a questionaire given through G-Form. Data analysis consisted of univariate, bivariate, and multivariate. The results of the study: most of the respondents washing their hands was in the good category (65.0\%), the respondents had high knowledge (59.2\%), positive attitudes (57.5\%), and good family support (56.7\%). The results of the bivariate analysis, all variables had a significant relationship with the act of washing hands in students, namely knowledge $(p=0.013$ and $O R=2.827$, attitude $(p=0.029$ and $O R=2.519)$, and family support $(p=0.0001$ and $O R=7,649)$ The result of multivariate analysis, the most dominant factor affecting the act of washing hands is knowledge (OR $=2.969$ ). Suggestions: so that the campus can provide health education, post health messages in the campus environment about the importance of preventing Covid-19, provide washing facilities supportive hand.

Keywords: Hand Washing, Prevention, Covid 19

\section{PENDAHULUAN}

Badan Kesehatan Dunia atau dikenal dengan WHO telah menetapkan sejak tanggal 12 Maret 2020, penyakit COVID-19 sebagai pandemik. Data yang terkumpul sampai dengan hari Rabu 18 Maret 2020 pukul 18.33, ternyata ada sebanyak 201.530 kasus positif Virus Corona, 8.007 orang pasien meninggal dunia, dan 82.034 orang lainnya dinyatakan sembuh (1). Sedangkan pertanggal 31 Mei 2020 pukul 01.30 WIB kasus pasien positif Covid-19 menjadi sebanyak 5.796.257 orang kasus, 362.483 orang pasien meninggal dunia (2).

Semakin cepatnya virus ini menyebar, menimbulkan kepanikan terhadap seluruh negara di dunia, begitu pula Indonesia. COVID-19 pertama di laporkan di Indonesia teptnya di Kota Depok Jawa Barat pada 02 Maret 2020, yaitu sebanyak dua kasus. Tanggal 31 Maret 2020 diperoleh data kasus yang dikonfirmasi menjadi sebanyak 1.528 kasus dan 136 kasus kematiian. Angka kejadian mortallitas COVID-19 di Indonesia sebesar $8,9 \%$, dan angka tersebut adalah yang paling tinggi di wilayah Asia Tenggara (3). Sedangkan pertanggal 31 Mei 2020 pukul 01.30 WIB kasus positif Covid-19 di Indonesia menjadi 25.773 orang positif, 7.015 orang meninggal dunia, dan 1.573 lainnya sembuh (2). Kondisi tersebut menggambarkan tingginya angka penularan penyakit Covid-19 yang berisiko terhadap kejadian kematian.

Berbagai tindakan untuk mencegah penyakit Covid-19 yang bisa dilakukan oleh masyarakat. Adapun upaya pencegahan yang paling baik yaitu melalui tindakan menghindar dari berbagai faktor yang kemungkinan dapat menjadi penyebab seseorang bisa terinfeksi oleh virus ini, antara lain dengan rutin melakukan cuci tangan dengan air menggunakan cairan pembunuh kuman, seperti halnya sabun atau cairan untuk membersihkan tangan (hand sanitizer) yang didalamnya terdapat kandungan alkohol minimal 60\%, utamanya 
dilakukan sesudah menjalani aktivitas di luar rumah ataupun di tempat umum (4).

Perilaku mencuci tangan adalah bagian dari indiikator Prilaku Hidup Bersiih dan Sehat (PHBS) yang digalakkan oleh pemerinth. Sebab tangan merupakan salah satu media penularan penyakit. Tangan menjadi salah satu tempat menempelnya bibit penyakit, salah satunya adalah virus corona. WHO dan Kemenkes RI merekomendasikan agar rajin untuk cuci tangan memakai sabun dan air mengalir. Oleh sebab itu, saat ini di berbagai fasilitas umum telah banyak disediakan fasilitas cuci tangan menggunakan sabun sbagai salah satu bentuk tindakan untuk mncegah penularan penyakit Covid-19. Namun demikian, kesadaran masyarakat terkait tindakan cuci tangan memakai sabun atau cairan pembersih tangan (hand sanitizer) sampai saat ini cenderung bervariasi. Karena Tindakan cuci tangan tersebut tidak sepenuhnya dilakukan dengan patuh oleh masyarakat Indonesia.

Berkaitan dengan Penanganan Pandemi Corona, Yurianto, menjelaskan bahwa lapisan pembungkus virus Corona tersusun atas lemak. Pembungkus itu sifatnya mudah rapuh apabila terpapar oleh deterjen. Bila pembungkusnya telah hancur ataupun tidak utuh, maka virus Corona yang mnempel menjadi lebih gampang mati sebelum dia masuk dan mnginfeksi badan manusia. Sehingga, risiko untuk terpapar Covid-19 cenderung lebih kecil. Berbagai macam sabun ataupun detergent yang bisa dipakai juga tidak memerlukan spesifikasi tertentu. Kita dapat memakai sabun biasa yang digunakan untuk cuci tangan. Tapi supaya hasilnya lebih optimal, alangkah baiknya sabun yang digunakan adalah sabun antiseptik (5).

Kondisi tersebut menggambarkan bahwa praktik cuci tangan sangatlah penting untuk dilakukan agar dapat mencegah penyakit. Menurut Notoatmodjo, pengetahuan merupakan salah satu faktor penting yang memberi kontribusi kepada tindakan individu, dan sumber pengetahuan diantaranya dapat diperoleh melalui penyampaian informasi langsung ataupun tidak langsung maupun melalui media elektronik dan media cetak, sehingga dengan pengetahuan yang diperoleh tersebut akan berpengaruh terhadap sikap setuju atau tidak setuju terhadap tindakan tersebut (6). Disamping itu, Green, menyebutkan tindakan juga dipengaruhi faktor penguat (reinforcing), diantaranya adalah melalui adanya dukungan dari orang terdekat, seperti halnya keluarga (7).

Beberapa penelitian sebelumnya tentang perilaku cuci tangan, seperti halnya penelitian Lestari, di Kelurahan Pegirian Kecamatan Sumampir Surabaya memperlihatkan ada hubungan yang signifikn antara pngetahuan dengan tndakan cuci tangan ( $p$ value $=0,009$ ) dan keeratan hubungan adalah kuat dengan koefisien korellasi yaitu 0,282. Terdapatnya hubungan antara sikap dengan tindakan mencuci tangan $(p$ value $=0,017)$ dan 
keeratan hubungannya adalah kuat dengan nilai koefisiien korelasi sebesar 0,271 (8).

Penelitian Effendi, di SD Negeri 08 Lubuklinggau juga menemukan bahwa terdapat 56 siswa $(52,8 \%)$ mempunyai pengetahuan baik dan 91 siswa $(85,8 \%)$ mempunyai prilaku cuci tangan memakai sabun juga baik. Kondisi tersebut menggambarkan adanya hubungan yang sgnifikan antara pengetahuan dengan prilaku mencuci tangan memakai sabun yang dilakukan responden (9).

Menurut beberapa penelitian ilmiah tersebut menunjukkan bahwa tindakan cuci tangan menggunakan pembersih baik sabun maupun cairan pembersih tangan lainnya, dinilai sangat penting kaitannya dengan upaya pencegahan penyakit yang dapat ditularkan melalui media tangan, seperti halnya penyakit covid-19. Oleh sebab itu, berbagai lapisan masyarakat dari balita sampai lanjut usia perlu menerapkan Tindakan cuci tangan menggunakan pembersih tersebut, sehingga penularan penyakit Covid-19 dapat dicegah seoptimal mungkin.

Mahasiswa Poltekkes Kemenkes Jakarta III khususnya Program Studi D-IV Fisioterapi, sampai saat ini sedang menjalankan proses pembelajaran jarak jauh sebagai salah satu bentuk kebijakan dari Pemerintah untuk memutus rantai penularan penyakit covid-19 di Indonesia. Namun demikian, terkait dengan tindakan cuci tangan untuk mencegah penularan penyakit covid-19, sampai saat ini belum diteliti. Hasil observasi pendahuluan, dengan melakukan wawancara menggunakan seluler terhadap 10 orang mahasiswa, mereka menyebutkan 5 orang diantaranya (50\%) tidak melakukan cuci tangan dengan cairan pembersih ataupun menggunakan hand sanitizer sesuai dengan ketentuan, dengan alasan lupa, dianggap tidak penting, dan tidak disuruh. Hal tersebut menggambarkan bahwa tindakan cuci tangan pada mahasiswa Program Studi D-IV Fisioterapi cenderung masih rendah. Hal tersebut kemungkinan akibat pengaruh dari banyak faktor, seperti pengetahuan, sikap, dan juga dukungan keluarga.

Tujuan penelitian yaitu untuk menganalisis hubungan tingkat pengetahuan, sikap, dan dukungan keluarga dengan tindakan cuci tangan dalam upaya mencegah penyakit Covid-19 pada mahasiswa Prodi D-IV Fisioterapi Poltekkes Kemenkes Jakarta III tahun 2020.

\section{METODE}

Penelitian analitik dan memakai desain cross sectional (potong lintang) (10). Lokasi atau tempat penelitian ini yaitu di Prodi D-IV Fisioterapi Poltekkes Kemenkes Jakarta III pada bulan Agustus - Oktober 2020.

Populasi dari penelitian ini yaitu seluruh mahasiswa yang ada di Prodi D-IV Fisioterapi Poltekkes Kemenkes Jakarta III. Hasil penghitungan sampel minimal sebanyak 117 orang. Untuk menentukan siswa yang diambil 
dari masing-masing kelas, maka digunakan metode simple random sampling dengan menggunakan perangkat lunak program SPSS (11). Dari hasil pengumpulan data, ternyata ada sebanyak 123 orang mahasiswa yang mengisi kuesioner dengan lengkap. Sehingga sampel penelitian ini menjadi 123 orang.

Penelitian ini menggunakan data primer. Cara melakukan pengumpulan data dalam penelitian ini yaitu memakai kuesioner yang terprogram dalam G-Form, yang isinya adalah pertanyaan mengenai tindakan cuci tangan, pengetahuan, sikap, dan dukungan keluarga Analisis Data dalam penelitian ini menggunakan analisis univariat atau distribusi frekuensi, analisis bivariat memakai uji Chi Square, dan analisis multivariat memakai Uji Regresi Logistik (12).

\section{HASIL DAN PEMBAHASAN}

\section{Analisis Univariat}

Tabel 1 Distribusi Frekuensi Tindakan

Cuci Tangan Pada Mahasiswa Program Studi DIV Fisioterapi Poltekkes Kemenkes Jakarta III Tahun 2020

\begin{tabular}{ccc}
\hline $\begin{array}{c}\text { Tindakan Cuci } \\
\text { Tangan }\end{array}$ & $\begin{array}{c}\text { Frekuensi } \\
\text { (n) }\end{array}$ & $\begin{array}{c}\text { Persentase } \\
\text { (\%) }\end{array}$ \\
\hline Kurang & 42 & 35,0 \\
\hline Baik & 78 & 65,0 \\
\hline Total & $\mathbf{1 2 0}$ & $\mathbf{1 0 0 , 0}$ \\
\hline
\end{tabular}

Menurut tabel 1, menunjukkan bahwa tindakan cuci tangan responden yang termasuk kategori kurang, yaitu 35,0\%, sedangkan yang termasuk dalam kelompok baik, sebesar $65,0 \%$.

Tabel 2 Distribusi Frekuensi Tingkat Pengetahuan, Sikap, dan Dukungan Keluarga Pada Mahasiswa Program Studi DIV Fisioterapi Poltekkes Kemenkes Jakarta III Tahun 2020

\begin{tabular}{cccc}
\hline Variabel & Kategori & $\begin{array}{c}\text { Frekuensi } \\
\text { (n) }\end{array}$ & $\begin{array}{c}\text { Persentase } \\
\text { (\%) }\end{array}$ \\
\hline \multirow{2}{*}{ Pengetahuan } & Rendah & 49 & 40,8 \\
& Tinggi & 71 & 59,2 \\
Sikap & Negatif & 51 & 42,5 \\
& Positif & 69 & 57,5 \\
Dukungan & Kurang & 52 & 43,3 \\
Keluarga & Baik & 68 & 56,7 \\
\hline Total & & $\mathbf{1 2 0}$ & $\mathbf{1 0 0 , 0}$ \\
\hline
\end{tabular}

Menurut tabel 2, menunjukkan responden yang memiliki pengetahuan tinggi sebanyak $59,2 \%$, sikap positif (57,5\%), dan dukungan keluarga baik $(56,7 \%)$.
Hasil analisis bivariat antara Pengetahuan, Sikap, dan Dukungan Keluarga dengan Tindakan Cuci Tangan pada mahasiswa memakai uji Kai Kuadrat, akan diperlihatkan pada tabel berikut. 
Tabel 3 Hasil Analisis Bivariat Hubungan Pengetahuan, Sikap, dan Dukungan Keluarga dengan Tindakan Cuci Tangan pada mahasiswa Program Studi DIV Fisioterapi

Poltekkes Kemenkes Jakarta III Tahun 2020

\begin{tabular}{|c|c|c|c|c|c|c|}
\hline \multirow[t]{2}{*}{ No } & \multirow[t]{2}{*}{ Variabel } & \multicolumn{2}{|c|}{ Tindakan Cuci Tangan } & \multirow[t]{2}{*}{ Total } & \multirow[t]{2}{*}{ Nilai $p$} & \multirow{2}{*}{$\begin{array}{c}\text { OR } \\
(95 \% \mathrm{Cl})\end{array}$} \\
\hline & & Kurang & Baik & & & \\
\hline \multirow[t]{3}{*}{1} & Pengetahuan & & & & & \\
\hline & Rendah & $\begin{array}{c}24 \\
(49,0 \%)\end{array}$ & $\begin{array}{c}25 \\
(51,0 \%)\end{array}$ & $\begin{array}{c}49 \\
(100 \%)\end{array}$ & \multirow{2}{*}{0,013} & 2,827 \\
\hline & Tinggi & $\begin{array}{c}18 \\
(25,4 \%)\end{array}$ & $\begin{array}{c}53 \\
(74,6 \%)\end{array}$ & $\begin{array}{c}71 \\
(100 \%)\end{array}$ & & $(1,303-6,132)$ \\
\hline \multirow[t]{3}{*}{2} & Sikap & & & & & \\
\hline & Negatif & $\begin{array}{c}24 \\
(47,1 \%)\end{array}$ & $\begin{array}{c}27 \\
(52,9 \%)\end{array}$ & $\begin{array}{c}51 \\
(100 \%)\end{array}$ & \multirow{2}{*}{0,029} & 2,519 \\
\hline & Positif & $\begin{array}{c}18 \\
(26,1 \%)\end{array}$ & $\begin{array}{c}51 \\
(73,9 \%)\end{array}$ & $\begin{array}{c}69 \\
(100 \%)\end{array}$ & & $(1,167-5,433)$ \\
\hline \multirow[t]{4}{*}{3} & $\begin{array}{l}\text { Dukungan } \\
\text { keluarga }\end{array}$ & & & & & \\
\hline & Kurang & $\begin{array}{c}31 \\
(59,6 \%)\end{array}$ & $\begin{array}{c}21 \\
(40,4 \%)\end{array}$ & $\begin{array}{c}51 \\
(100 \%)\end{array}$ & \multirow{2}{*}{0,0001} & \multirow{2}{*}{$\begin{array}{c}7,649 \\
(3,268-17,907)\end{array}$} \\
\hline & Baik & $\begin{array}{c}11 \\
(16,2 \%)\end{array}$ & $\begin{array}{c}57 \\
(83,8 \%)\end{array}$ & $\begin{array}{c}68 \\
(100 \%)\end{array}$ & & \\
\hline & Total & $\begin{array}{c}42 \\
(35,0 \%)\end{array}$ & $\begin{array}{c}78 \\
(65,0 \%)\end{array}$ & $\begin{array}{c}120 \\
(100 \%)\end{array}$ & & \\
\hline
\end{tabular}

Berdasarkan tabel 3, diketahui proporsi Tindakan cuci tangan baik, lebih banyak ditemukan pada responden yang pengetahuannya tinggi $(74,6 \%)$, sikap positif $(73,9 \%)$, dan dukungan keluarga baik $(83,8 \%)$.

Hasil uji statistik diperoleh seluruh variabel memiliki hubungan signifikan dengan Tindakan cuci tangan yaitu pengetahuan $(p=$ 0,013 dan $O R=2,827)$, sikap $(p=0,029$ dan $O R$ $=2,519)$, dan dukungan keluarga $(p=0,0001$ dan $O R=7,649$ ).

Analisis multivariat memiliki tujuan mendapatkan suatu model terbaik dalam melihat hubungan pengetahuan, sikap, dan dukungan keluarga dengan Tindakan cuci tangan pada mahasiswa. Dalam pemodelan ini seluruh variabel kandidat diujicobakan membentuk model persamaan. Model dipilih dengan memakai metode Enter dengan memasukan kemungkinan bentuk variasi model dan tidak menyerahkn seluruhnya pada analisis yang dilakukan (13).

Hasil akhir analisis multivariat ternyata hanya dua variabel independen yang lolos. Hasilnya dapat dilihat dalam tabel berikut :

Tabel 4 Hasil Akhir Analisis Regresi Logistik Antara Variabel Pengetahuan dan Dukungan Keluarga 


\begin{tabular}{lccc}
\hline Variabel & P & OR & Cl.95\% \\
\hline Pengetahuan & 0,007 & 2,969 & $\begin{array}{c}1,339- \\
6,582\end{array}$ \\
\hline $\begin{array}{l}\text { Dukungan } \\
\text { keluarga }\end{array}$ & 0,030 & 1,225 & $\begin{array}{c}1,020- \\
1,472\end{array}$ \\
\hline
\end{tabular}

Menurut tabel 4, menemukan adanya 2 variabel yang mempunyai $p$ value $<0,05$, yaitu pengetahuan dan dukungan keluarga, dengan demikian dapat ditarik kesimpulan bahwa variabel pengetahuan dan dukungan keluarga berhubungan secara bermakna dengan tindakan cuci tangan yang baik, dan tidak ada yang menjadi variabel confounding karena dalam analisis multivariat, tidak ada variabel yang mengalami perubahan $\mathrm{OR}>10 \%$.

Hasil dari analisis secara multivariat, menemukan faktor dominan tertinggi yang memiliki hubungan dengan tindakan cuci tangan yaitu pengetahuan $(\mathrm{OR}=2,969$ dan $\mathrm{Cl}$ 95\% 1,339-6,582), artinya mahasiswa yang pengetahuannya tinggi akan berpeluang 2,969 kali lebih baik dalam melakukan tindakan cuci tangan dibandingkan dengan mahasiswa yang memiliki pengetahuan rendah setelah dikontrol variabel dukungan keluarga.

Pengetahuan dapat didefinisikan sebagai hasil dari tahu dan hal ini dapat terjadi sesudah individu tersebut melakukan penginderaan kepada suatu obyek khusus. Penginderan dilakukan menggunakan pancaindera manusia, diantaranya indera untuk melihat, mendengar, penciuman, perasa dan peraba. Sebagian besar pengetahuan tersebut didapat seseorang menggunakan indra penglihatan dan pendengaran (6).

Sampai saat ini, penelitian terkait dengan prilaku cuci tangan dalam pencegahan penyakit covid-19 khususnya di Indonesia terus dikembangkan, beberapa penelitian sebelumnya tentang perilaku cuci tangan, seperti halnya penelitian Effendi, di SD Negeri 08 Lubuklinggau juga menemukan bahwa ada sebanyak 56 siswa (52,8\%) berpengetahuan baik dan 91 orang siswa $(85,8 \%)$ ternyata mempunyai perilaku mencuci tangan memakai sabun termasuk dalam kategori baik. Hal tersebut menggambarkan adanya hubungan yang brmakna antara pengetahuan dengan perilaku mencuci tangan memakai sabun yang di kerjakan oleh responden (9).

Mahasiswa yang memiliki pengetahuan tinggi terkait dengan usaha mencegah Covid-19 melalui praktik mencuci tangan, maka dapat menjadi faktor predisposisi atau faktor pencetus yang baik sehingga dia akan melakukan tindakan cuci tangan tersebut secara baik dan juga konsisten atau terus menerus.

Terkait dengan sikap responden, ternyata dalam penelitian jni sikap memiliki hubungan bermakna dengan Tindakan cuci tangan. Hal tersebut ternyata sesuai dengan teori yang menjelaskan bahwa sikap yaitu reaksi ataupun respon ndividu trhadap adanya suatu rangsangan ataupun obyek yang masih belum terbuka atau belum terlihat (6). Sikap tersebut bisa bersifat positif ataupun bersifat negatif. Jika bersikap positif maka kecenderungan atas 
tindakannya yaitu dia akan berupaya untuk dekat, senang, berharap akan obyek tertentu. Namun jika sikap tersebut adalah negatif maka ada kecenderungn bahwa seseorang tersebut akan jauh, menghindar, benci, ataupun tidak suka terhadap obyek tertentu (14).

Hasil penelitian ini juga sejalan dengan penelitian Lestari, di Kelurahan Pegirian Kecamatan Sumampir Surabaya yang memperlihatkan adanya hubungan antara sikap dengan tindakan cuci tangan yang dilakukan responden dengan nilai $p=0,017(8)$.

Mahasiswa yang memiliki sikap positif tentang tindakan cuci tangan, menggambarkan ia mendukung dan setuju dengan tindakan tersebut. Sehingga secara otomatis menjadi faktor predisposisi atau faktor pencetus untuk dapat menimbulkan tindakan berupa praktik cuci tangan yang dilakukannya sesuai dengan anjuran pemerintah. Oleh sebab itu, sangat penting untuk membentuk sikap positif pada diri responden agar bisa mendukung perilakunya dalam melakukan cuci tangan memakai sabun sebagai upaya untuk mencegah penyakit Covid-19.

Disamping pengetahuan dan sikap, dukungan keluarga juga sebagai faktor yang berpengaruh dalam penelitian ini. Dukungan keluarga yaitu sebuah urutan kejadian yang dialami semasa hidup seseorang. Adapun sifat dan jenis dari dukungan akan berbeda diberbagai tahapan kehidupan. Dukungan keluarga dapat dalam bentuk dukungan sosial dari dalam, seperti dukungan yang berasal dari suaminya, isterinya, ataupun dukungan dari saudara sekandung, dan bisa juga berupa dukungan keluarga dari luar keluarga inti. Dukungn keluarga tersebut akan menjadikan keluarga memiliki kemampuan untuk jalankan fungsinya menggunakan berbagai kepintaran dan akal, sehingga kondisi tersebut dapat meningkatkan kesehatan dan juga adaptasi dalam keluarga (15).

Green menjelaskan bahwa keluarga merupakan salah satu faktor penguat dalam kerangka perilaku. Selain itu, dukungan keluarga juga menjadi kelompok referensi, yang keberadaannya akan memberikan pengaruh pada perilaku masyarakat dalam menggunakan layanan kesehatan (7). Dalam hal ini adalah perilaku mencuci tangan memakai sabun yang dilakukan oleh responden.

Penelitian Norfai dan Anam di SDN Standar Nasional Pelambuan 4 Kota Banjarmasin menemukan bahwa dari hasil uji statistk hubungan antara dukungan orang tua dengan perilaku cuci tangan yang benar didapatkan nilai $p$ sebesar 0,000 , berarti adanya hubungan yang signifikan diantara dukungan orang tua dengan perilaku cuci tangan yang benar. Hal tersebut memberikan gambaran bukti bahwa faktor dukungan orang tua sangatlah besar perannya terhadap prilaku anak untuk cuci tangan secara benar dan baik, sebab orangtua merupakan orang paling dekat yang bisa untuk selalu mengingatkan anak-anaknya agar dapat mencuci tangannya secara benar dan baik (16). 
Hal tersebut menggambarkan bahwa dukungan keluarga seperti halnya orangtua maupun saudara lainnya khususnya yang dekat dan tinggal serumah, memiliki kontribusi yang bermakna dalam mengubah tindakan mahasiswa untuk melakukan cuci tangan yang benar dalam upaya mencegah penyakit Covid19.

Dari analisis multivariat juga membuktikan bahwa pengetahuan sebagai faktor dominan yang mempengaruhi tindakan cuci tangan pada mahasiswa. Penelitian Lestari di Kelurahan Pegirian Kecamatan Sumampir Surabaya yang memperlihatkan ada hubungan yang signifikan antara pengetahuan dengan praktik cuci tangan yaitu dari hasil $p$ value $=0,009$ dan keeratan hubungan yang sifatnya kuat dengan koefisien korelasi yaitu $0,282(8)$.

Mahasiswa yang memiliki pengetahuan tinggi tentang praktik cuci tangan dan usaha mencegah penyakit Covid-19, menjadi faktor pencetus yang sangat baik dalam meningkatkan tindakan cuci tangan yang dilakukan, apalagi didukung oleh adanya semangat dan motivasi dari keluarga, yang sekaligus menjadi faktor penguat bagi mahasiswa dalam bertindak melakukan cuci tangan sebagai usaha untuk mencegah penyakit Covid-19

\section{SIMPULAN}

Hasil penelitian diperoleh sebagian besar tindakan cuci tangan responden termasuk kategori baik $(65,0 \%)$, responden berpengetahuan tinggi (59,2\%), sikap positif (57,5\%), dan dukungan keluarga baik $(56,7 \%)$.

Hasil analisis bivariat, seluruh variabel mempunyai hubungan signifikan dengan tindakan cuci tangan pada mahasiswa, yaitu pengetahuan $(p=0,013$ dan $0=2,827$, sikap $(p=0,029$ dan $O R=2,519)$, dan dukungan keluarga $(p=0,0001$ dan $O R=7,649)$.

Hasil analisis multivariat, faktor dominan paling tinggi yang mempengaruhi tindakan cuci tangan adalah pengetahuan $(\mathrm{OR}=2,969)$

\section{UCAPAN TERIMAKASIH :}

Terimakasih disampaikan kepada Direktur Poltekkes Kemenkes Jakarta III beserta jajarannya, Ketua Jurusan Fisioterapi, Ketua Program Studi Sarjana Terapan Fisioterapi, beserta seluruh jajaran manajemen yang ada di Jurusan Fisioterapi, yang sudah mendukung jalannya kegiatan penelitian ini.

\section{DAFTAR PUSTAKA :}

1. Zahrotunnimah. (2020). Langkah Taktis Pemerintah Daerah Dalam Pncegahan Pnyebaran Virus Corona Covid-19 di Indonesia. SALAM; Jurnal Sosial \& Budaya Syar-I FSH UIN Syarif Hidayatullah Jakarta, 7 No. 3, 247-260. https://doi.org/10.15408/sjsbs.v7i3.15103

2. BNPB. (2020). Situasi Terkini Perkembangan Coronavirus Disease (COVID-19) 31 Mei 2020. www.google.com.

3. Susilo. (2020). Coronavirus Disease 2019. Jurnal Penyakit Dalam Indonesia, 7, No. 1, 
$45-67$.

4. Alodokter. (2020). Virus Corona (Covid-19). www.google.com.

5. Aidohealth. (2020). Cegah Infeksi Covid-19, Cuci Tangan Harus Pakai Sabun Khusus. Benarkah? www.google.com

6. Notoatmodjo, S. (2012). Pendidikan Kesehatan dan Ilmu Perilaku. Rineka Cipta.

7. Green, L. (1980). Health Education Planning. A Diagnostic Approach. Mafield Publishing Company.

8. Lestari. (2019). Hubungan Pengetahuan Dan Sikap Terhadap Prilaku Cuci Tangan Pada Masyarakat Kel Pegirian. Jurnal Promkes: The Indonesian Journal of Health Promotion and Health Education, Vol. 7 No., 1-11. https://doi.org/10.20473/jpk.V7.I1.2019.111

9. Effendi. (2019). Faktor-Faktor Yang Berhubungan Dengan Prilaku Mencuci Tangan Menggunakan Sabun Pada Siswa Di SD Negeri 08 Lubuk Linggau. Journal of Nursing and Public Health. JNPH, Volume 7 $N, 62-71$.

10. Notoatmodjo, S. (2015). Metodologi Penelitian Kesehatan. Penerbit Rineka
Cipta.

11. Arikunto, Suharsini. 2006. Prosedur Penelitian Suatu Pendekatan Praktek. Penerbit Rineka Cipta. Jakarta.

12. Sabri \& Hastono, 2008. Statistik Kesehatan. Edisi Revisi. Penerbit PT Raja Grafindo Persada. Jakarta.

13. Hastono, S. (2012). Analisis Data. Fakultas Kesehatan Masyarakat Universitas Indonesia.

14. Suparyanto. (2012). Konsep Sikap. http://dr-suparyanto.blogspot.com

15. Friedman. (2010). Buku Ajar Keperawatan Kerluarga : Riset Teori \& Praktik. Alih bahasa oleh Achir Yani S. (E. Tiar (ed.)). EGC.

16. Norfai dan Anam. (2017). Hubungan Antara Pengetahuan, Dukungan Orang Tua Dan Dukungan Guru Dengan Prilaku Cuci Tangan Yg Benar Di SDN Standar Nasional Pelambuan 4 Kota Banjarmasin Tahun 2016. Jurnal Kesehatan Masyarakat Khatulistiwa (JKMK). http://openjurnal.unmuhpnk.ac.id/index.p hp?journal=jkmk\&page=index 